
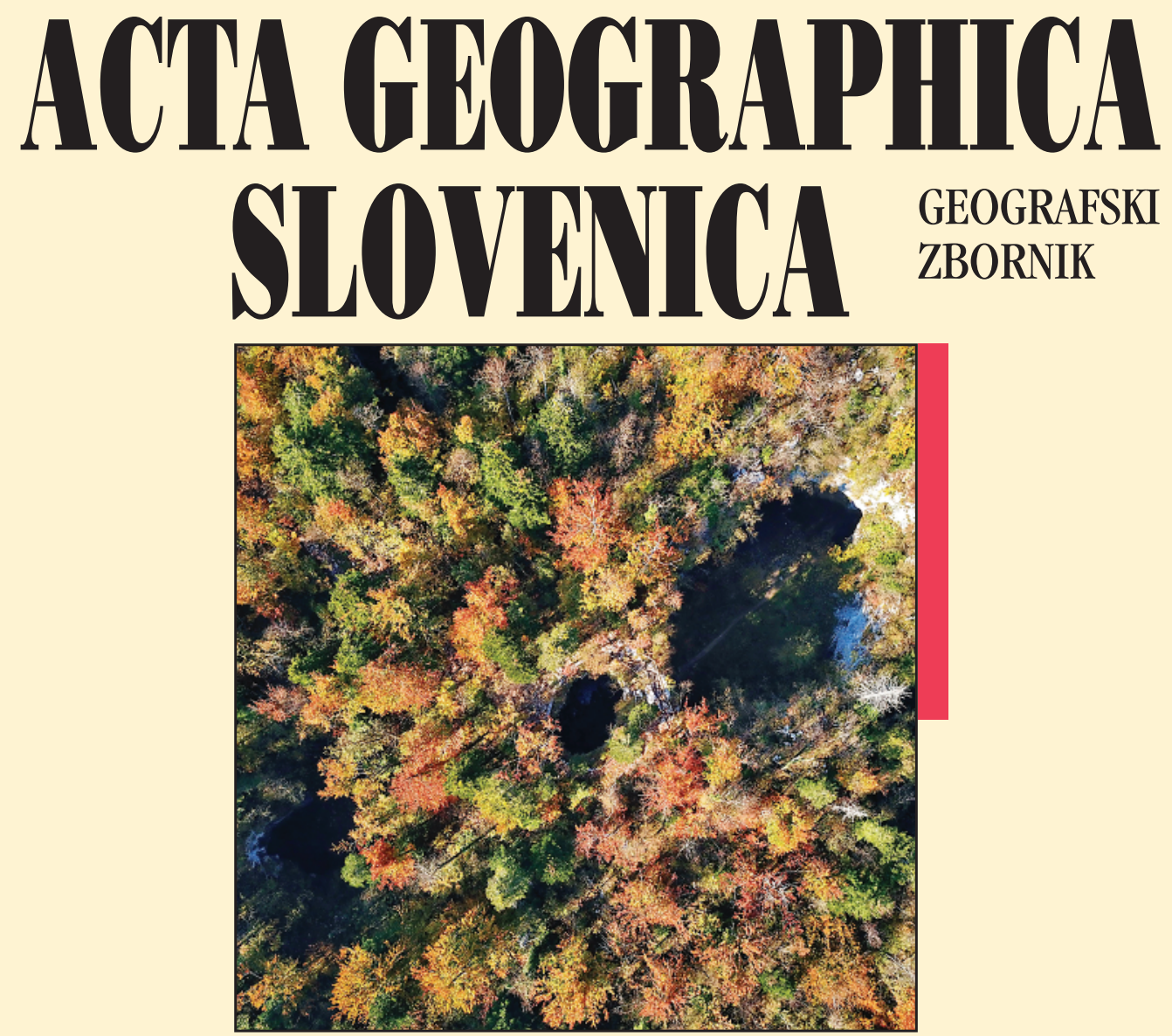


\section{ACTA GEOGRAPHICA SLOVENICA GEOGRAFSKI ZBORNIK \\ $59-2 \cdot 2019$}

\section{Contents}

Drago PERKO, Rok CIGLIČ, Mauro HRVATIN

The usefulness of unsupervised classification methods for landscape typification: The case of Slovenia

Vladimir M. CVETKOVIĆ, Kevin RONAN, Rajib SHAW, Marina FILIPOVIĆ, Rita MANO, Jasmina GAČIĆ, Vladimir JAKOVLJEVIĆ

Household earthquake preparedness in Serbia: A study of selected municipalities

Iwona CIEŚLAK

Spatial conflicts: Analyzing a burden created by differing land use

Ivan PAUNOVIĆ, Verka JOVANOVIĆ

Sustainable mountain tourism in word and deed: A comparative analysis in the macro regions of the Alps and the Dinarides

Nikola Darko VUKSANOVIĆ, Dragan TEŠANOVIĆ, Bojana KALENJUK, Milijanko PORTIĆ Gender, age and education differences in food consumption within a region: Case studies of Belgrade and Novi Sad (Serbia)

\section{Special issue - Franciscean cadaster as a source of studying landscape changes}

Matej GABROVEC, Ivan BIČÍK, Blaž KOMAC

Land registers as a source of studying long-term land-use changes

Ivan BIČÍK, Matej GABROVEC, Lucie KUPKOVÁ

Long-term land-use changes: A comparison between Czechia and Slovenia

Lucie KUPKOVÁ, Ivan BIČÍK, Zdeněk BOUDNÝ

Long-term land-use / land-cover changes in Czech border regions

Drago KLADNIK, Matjaž GERŠIČ, Primož PIPAN, Manca VOLK BAHUN

Land-use changes in Slovenian terraced landscapes

Daniela RIBEIRO, Mateja ŠMID HRIBAR

Assessment of land-use changes and their impacts on ecosystem services in two Slovenian rural landscapes

Mojca FOŠKI, Alma ZAVODNIK LAMOVŠEK

Monitoring land-use change using selected indices

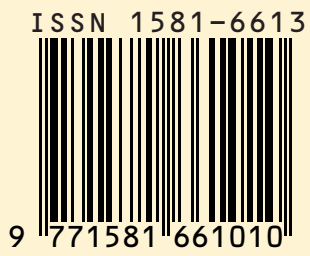




\section{ACTA GEOGRAPHICA SLOVENICA}

$59-2$

2019

ISSN: 1581-6613

COBISS: 124775936

UDC/UDK: 91

(C) 2019, ZRC SAZU, Geografski inštitut Antona Melika

International editorial board/mednarodni uredniški odbor: David Bole (Slovenia), Michael Bründl (Switzerland), Rok Ciglič (Slovenia), Matej Gabrovec (Slovenia), Matjaž Geršič (Slovenia), Peter Jordan (Austria), Drago Kladnik (Slovenia), Blaž Komac (Slovenia), Andrej Kranjc (Slovenia), Dénes Lóczy (Hungary), Simon McCharty (United Kingdom), Slobodan Marković (Serbia), Janez Nared (Slovenia), Drago Perko (Slovenia), Marjan Ravbar (Slovenia), Nika Razpotnik Visković (Slovenia), Aleš Smrekar (Slovenia), Annett Steinführer (Germany), Mimi Urbanc (Slovenia), Matija Zorn (Slovenia)

Editor-in-Chief/glavni urednik: Blaž Komac; blaz@zrc-sazu.si

Executive editor/odgovorni urednik: Drago Perko; drago@zrc-sazu.si

Chief editor for physical geography/glavni urednik za fizično geografijo: Matija Zorn; matija.zorn@zrc-sazu.si Chief editor for human geography/glavna urednica za humano geografijo: Mimi Urbanc; mimi@zrc-sazu.si

Chief editor for regional geography/glavni urednik za regionalno geografijo: Drago Kladnik; drago.kladnik@zrc-sazu.si

Chief editor for spatial planning/glavni urednik za regionalno planiranje: Janez Nared; janez.nared@zrc-sazu.si

Chief editor for rural geography/glavna urednica za geografijo podeželja: Nika Razpotnik Visković; nika.razpotnik@zrc-sazu.si Chief editor for urban geography/glavni urednik za urbano geografijo: David Bole; david.bole@zrc-sazu.si

Chief editor for geographic information systems/glavni urednik za geografske informacijske sisteme: Rok Ciglič; rok.ciglic@zrc-sazu.si

Chief editor for environmental protection/glavni urednik za varstvo okolja: Aleš Smrekar; ales.smrekar@zrc-sazu.si

Editorial assistant/uredniški pomočnik: Matjaž Geršič; matjaz.gersic@zrc-sazu.si

Issued by/izdajatelj: Geografski inštitut Antona Melika ZRC SAZU

Published by/založnik: Založba ZRC

Co-published by/sozaložnik: Slovenska akademija znanosti in umetnosti

Address/Naslov: Geografski inštitut Antona Melika ZRC SAZU, Gosposka ulica 13, SI - 1000 Ljubljana, Slovenija

The papers are available on-line/prispevki so dostopni na medmrežju: http://ags.zrc-sazu.si (ISSN: 1581-8314)

Ordering/naročanje: Založba ZRC, Novi trg 2, p. p. 306, SI - 1001 Ljubljana, Slovenija; zalozba@zrc-sazu.si

Annual subscription/letna naročnina: $20 €$ for individuals/za posameznike, $28 €$ for institutions/za ustanove.

Single issue/cena posamezne številke: $12,50 €$ for individuals/za posameznike, $16 €$ for institutions/za ustanove.

Cartography/kartografija: Geografski inštitut Antona Melika ZRC SAZU

Translations/prevodi: DEKS, d. o. o.

DTP/prelom: SYNCOMP, d. o. o.

Printed by/tiskarna: Tiskarna Present, d. o. o.

Print run/naklada: 450 copies/izvodov

The journal is subsidized by the Slovenian Research Agency and is issued in the framework of the Geography of Slovenia core research programme (P6-0101)/revija izhaja s podporo Javne agencije za raziskovalno dejavnost Republike Slovenije in nastaja v okviru raziskovalnega programa Geografija Slovenije (P6-0101).

The journal is indexed also in/revija je vključena tudi v: SCIE - Science Citation Index Expanded, Scopus, JCR - Journal Citation Report/Science Edition, ERIH PLUS, GEOBASE Journals, Current geographical publications, EBSCOhost, Geoscience e-Journals, Georef, FRANCIS, SJR (SCImago Journal \& Country Rank), OCLC WorldCat, Google scholar, and CrossRef

Oblikovanje/Design by: Matjaž Vipotnik

Front cover photography: Exploration of the collapse dolines, such as the one at the Small Natural Bridge in Rakov Škocjan, has enabled a deeper understanding of karst processes in recent years (photograph: Matej Lipar).

Fotografija na naslovnici: Raziskave udornice, kot je ta pri Malem Naravnem mostu v Rakovem Škocjanu, so v zadnjih letih omogočile globlje razumevanje kraških procesov (fotografija: Matej Lipar). 


\section{ASSESSMENT OF LAND-USE CHANGES AND THEIR IMPACTS ON ECOSYSTEM SERVICES IN TWO SLOVENIAN RURAL LANDSCAPES}

Daniela Ribeiro, Mateja Šmid Hribar

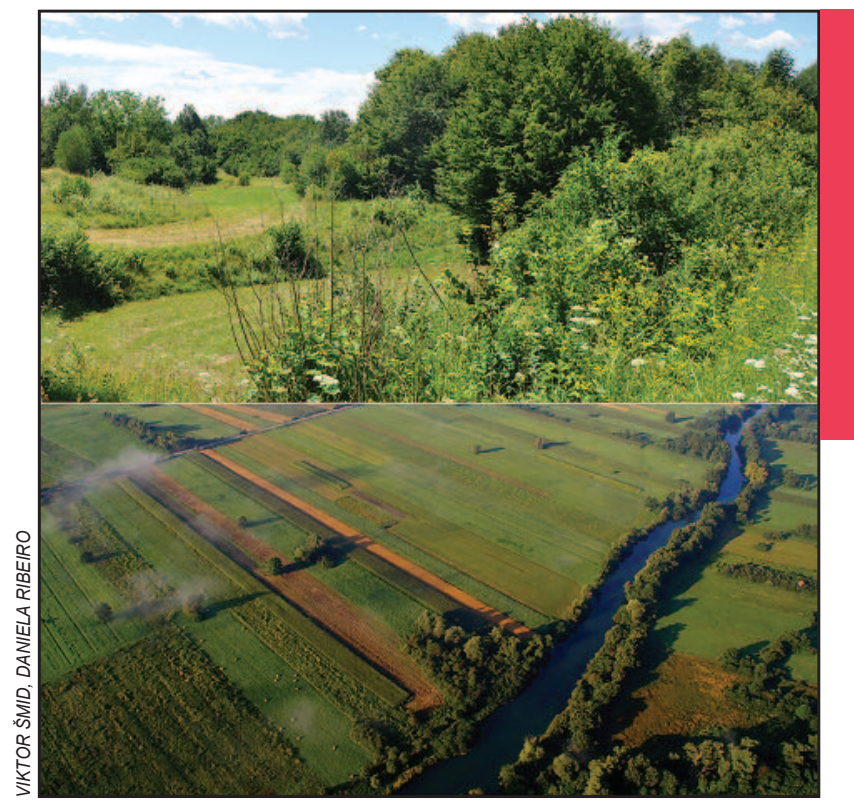

Due to the karst features human activities are limited and the landscape of Bela krajina is being overgrown (upper).

The landscape of the Ljubljana Marsh is largely composed of various meadows, fields, pastures, canals, hedges, tall herb communities, and shrubs (down). 
DOI: https://doi.org/10.3986/AGS.6636

UDC: 913:711.14(497.4)

711.14:711.3(497.4)

COBISS: 1.01

\title{
Assessment of land-use changes and their impacts on ecosystem services in two Slovenian rural landscapes
}

\begin{abstract}
This study shows the link between land use, landscape changes, and ecosystem services. Two pilot areas were investigated for how land use changes from 1824 to 2013 affect the provision of ecosystem services. It was found that low-intensity managed traditional land use is disappearing due to the intensification of agricultural production on the one hand, and the retreat of agriculture from unfavorable areas on the other hand. However, such traditional land use contributes to more diverse and more numerous ecosystem services and helps preserve the cultural landscape. Therefore, intensification and overgrowth should be restricted, and less intensive agriculture should be encouraged. The approach presented can be used as a support tool for decision-making in managing and governing landscapes.
\end{abstract}

KEY WORDS: land use, ecosystem services, Franciscean Land Cadaster, Revised Land Cadaster, field mapping, Bela krajina, Ljubljana Marsh

\section{Ocena sprememb rabe zemljišč in njihov vpliv na ekosistemske storitve $v$ dveh podeželskih pokrajinah $\mathrm{v}$ Sloveniji}

POVZETEK: Namen študije je pokazati povezavo med rabo zemljišč, pokrajinskimi spremembami in ekosistemskimi storitvami. Na dveh pilotnih območjih smo preučevali, kako je sprememba rabe zemljičč med leti 1824 in 2013 vplivala na zagotavljanje ekosistemskih storitev. Ugotovili smo, da tako zaradi intenziviranja kmetijske pridelave, kot tudi opuščanja kmetijstva na manj ugodnih območjih, izginja tradicionalna manj intenzivna raba zemljišč. Vendar pa prav tovrstna tradicionalna raba prispeva več bolj raznolikih ekosistemskih storitev ter pripomore k ohranjanju kulturne pokrajine. Zaradi tega bi bilo treba omejevati intenzifikacijo in zaraščanje, ter spodbujati obstoj manj intenzivnega kmetijstva. Predstavljeni pristop lahko služi kot podporno orodje pri odločanju za upravljanje in gospodarjenje s pokrajinami.

KLJUČNE BESEDE: raba zemljišč, ekosistemske storitve, franciscejski kataster, reambulančni kataster, terensko kartiranje, Bela krajina, Ljubljansko barje

\section{ADDRESSES:}

\section{Daniela Ribeiro, Mateja Šmid Hribar}

Research Centre of the Slovenian Academy of Sciences and Arts, Anton Melik Geographical Institute daniela.ribeiro@zrc-sazu.si,mateja.smid@zrc-sazu.si

This article was submitted for publication on February $14^{\text {th }}, 2018$.

Uredništvo je prejelo prispevek 14. februarja 2018. 


\section{Introduction}

The landscape, as a combination of abiotic, biotic, and cultural elements, provides ecological functions and ecosystem services essential for the existence of the human race (Millennium Ecosystem Assessment 2005). The landscape structure is influenced by human activities, particularly by land use that shapes socioeconomic development and modifies the structure and processes in the environment (Mander and Uuemaa 2010). Changes in the landscape's structure result in changes to its functions and consequently to ecosystem services as well. As a result of land-use changes, European landscapes have undergone rapid transformation (European Landscape Convention 2000). Two dominant trends in land-use changes are overgrowth due to agriculture marginalization and land abandonment, and land intensification due to more intensive agricultural production on a larger scale (Fry and Gustavsson 1996, Bender et al. 2005).

In Slovenia, various studies have examined land-use changes (e.g. Gabrovec and Kladnik 1997; Petek 2002; Petek and Urbanc 2004; Hladnik 2005; Paušič and Čarni 2012; Lisec, Pišek and Drobne 2013; Ribeiro, Ellis Burnet and Torkar 2013; Šmid Hribar 2016; Gabrovec and Kumer 2019). However, no one has tackled the effects of land-use changes on ecosystem services.

Ecosystem services are the direct and indirect contributions of ecosystems to human wellbeing (Kumar 2010). They have become an important tool for a wide range of decision-making contexts (Fisher, Turner and Morling 2009; de Groot et al. 2010). Transformation of natural ecosystems into other forms of land use alters the landscape's functioning and consequently the supply of ecosystem services. These changes often result in short-term economic benefits (Braat et al. 2008), but in the long run they may reduce and degrade regulating ecosystem services that are vitally important for people. Previous studies have shown that the provision of ecosystem services depends on biophysical conditions and landscape management practices (e.g., Ceschia et al. 2010; Otieno et al. 2011; Burkhard et al. 2012; Haines-Young, Potschin and Kienast 2012; Bürgi et al. 2015; Frélichová and Fanta 2015; Makovníková, Kanianska and Kizeková 2017). Frélichová and Fanta (2015) have proven that land-use intensification contributes to the decline of diversity and ecosystem services because landscapes are often converted to single-purpose land-use (Braat et al. 2008). On the other hand, underuse or no use also significantly impacts and threatens the multifunctionality of landscapes and consequently biocultural diversity and flows of ecosystem services (Mauerhofer et al. 2018). Hence, structural and functional landscape changes might result in a loss of diverse ecosystem services.

This study examines the link between landscapes, changes to them, and the ability to provide ecosystem services. It presents a novel approach to understanding the functioning of landscapes that can be used as an advanced decision-making tool for managing and governing landscapes. Based on two pilot areas, we investigated how land-use changes affect the provision of ecosystem services in Slovenia.

\subsection{Pilot areas}

We selected two pilot areas as examples of the two dominant trends in land-use changes. The first pilot area, Črna vas, is located in the Ljubljana Marsh Protected Landscape Area (IUCN Category V) near the capital city, Ljubljana. Črna vas is a Slovenian settlement where the landscape has changed significantly. The greatest changes occurred at the beginning of the nineteenth century, when extensive drainage was carried out in order to obtain new farmland. The drainage work was finished in 1829, and colonization of the area followed (Melik 1927). A major change to the landscape was also caused by intensive peat extraction, which lowered the surface by several meters in many areas and increased the risk of floods, and therefore floods are still common (Smrekar et al. 2016). The most important driving forces that shape today's landscape include intensive farming, nature protection, and urbanization due to the proximity of Ljubljana (Šmid Hribar 2016).

The second pilot area, Bojanci, is located in Bela krajina in southeastern Slovenia. In Bela krajina the use of the space, and its patterning and economic structure, are influenced by interlacing karst and Pannonian geographical characteristics (Plut 2008). Until the Second World War, people from Bela krajina mainly worked in and made a living from agriculture (Dražumerič 1987). However, due to the karst landscape features, cultivation is connected to great investments in land improvement, and the natural conditions do not allow the development of intensive agriculture in the region (Ciglič et al. 2012; Ribeiro 2017). For a variety of reasons, emigration from the area was common, and the population continued to decline, with a consequent increase in land abandonment. As a result, today the region is grappling with significant social and economic challenges (Ribeiro 2017). 


\section{Methods}

\subsection{Data}

To determine long-term landscape changes, we applied data from the Franciscean Land Cadaster (Franciscejski kataster ... 1824; 1825), the Revised Land Cadaster (Reambulančni kataster ... 1869; 1877), and habitat mapping (Habitatni tipi ... 2009, Čarni et al. 2011) combined with fieldwork (in 2013), which represented the current land use. The historical maps were first scanned and georeferenced, and then converted to vector format for further analysis.

To demonstrate the land use for 1824 and 1825, we used the Franciscean Land Cadaster for Carniola, which is a valuable data source for studying the cultural landscape of the nineteenth century (Ribnikar 1982; Petek and Urbanc 2004). Data for the next period (1869 and 1877) were obtained from the Revised Land Cadaster for Carniola. In determining land use, we used the descriptive part of the two cadasters, in which each land plot is defined by land use. In rare cases in which the use was not known or unreadable, we identified it as »unknown«.

For the current land use, habitat mapping data were used combined with our field mapping. Data for the Črna vas pilot area were acquired from the mapping of habitat types carried out in 2009 for the Ljubljana Marsh area (Erjavec et al. 2009). Data for the Bojanci pilot area were acquired from the mapping of habitat types carried out in 2011 for the Marindol area (Čarni et al. 2011). The habitat mapping data were converted into land use type data (Table 1, column 1). In the case of doubt, additional fieldwork was conducted for Črna vas in 2013. For instance, certain habitat types, such as alder swamp woods, were sometimes classified as hedgerows and sometimes groves according to land use and field observations. The same principle was used for rare land plots in which two or even three different habitat types were mapped.

\subsection{Analysis of land use changes}

In order to make comparisons over time, the datasets were thematically generalized (Ribeiro, Ellis Burnet and Torkar 2013). Table 1 shows how the land use categories were classified in the datasets used, as well as the corresponding CORINE Land Cover category (European Environmental Agency 1995), which allows an international comparison. Because the datasets used were prepared for different needs, the main challenge of categorization was to unify various detailed datasets, which is subjective to a certain degree. In ArcGIS 10, we examined the topology of all digital land use layers and eliminated the errors. For each of the two pilot areas, we produced land use maps $(1825,1869,2013$ for Črna vas, and 1824, 1877, 2011 for Bojanci). The land use change maps were produced by successively overlaying the three temporal spatial data layers (Figure 1).

\subsection{Assessment of ecosystem services}

The assessment of ecosystem services was based on the matrix for the assessment of various land use types' capacities to provide ecosystem services, as proposed by Burkhard et al. (2009; Table 2). The »recreational and aesthetic values « (see Table 2, cultural services column) were divided into two separate criteria, and

Table 1: Land-use categories in the pilot areas from 1824 until 2013 (sources: Franciscejski kataster ... 1824; 1825, Reambulančni kataster ... 1869; 1877, Habitatni tipi . . . 2009, Čarni et al. 2011, Šmid Hribar 2016).

\begin{tabular}{lllll}
\hline Land-use type (2013) & $\begin{array}{l}\text { Franciscean Land Cadaster } \\
\text { (1824 and 1825) }\end{array}$ & $\begin{array}{l}\text { Revised Land Cadaster } \\
\text { (1869 and 1877) }\end{array}$ & $\begin{array}{l}\text { Habitat mapping } \\
\text { (2009 and 2011) }\end{array}$ & CORINE land cover \\
\hline Cultivated field & Cultivated field & Cultivated field & 82.11 Field crops & 2.1.1 Non-irrigated arable land \\
\hline Extensive orchard & Orchard & Orchard & $\begin{array}{l}83.151 \text { Northern fruit } \\
\text { orchards }\end{array}$ & $\begin{array}{l}\text { 2.2.2 Fruit trees and berry } \\
\text { plantations }\end{array}$ \\
\hline Garden & Garden with fruit trees & $\begin{array}{l}\text { Garden with fruit trees } \\
\text { Vegetable garden }\end{array}$ & $\begin{array}{l}\text { 83.15 Fruit orchards } \\
\text { 85.3 Gardens }\end{array}$ & $\begin{array}{l}\text { 2.2.2. Fruit trees and berry } \\
\text { plantations }\end{array}$ \\
\hline
\end{tabular}


Acta geographica Slovenica, 59-2, 2019

\begin{tabular}{|c|c|c|c|c|}
\hline Intensive meadow & - & - & $\begin{array}{l}38.222 \text { Hygromesophile } \\
\text { medio-European lowland } \\
\text { hay meadows }\end{array}$ & $\begin{array}{l}\text { 2.1.1 Non-irrigated arable } \\
\text { land }\end{array}$ \\
\hline $\begin{array}{l}\text { Extensive to medium- } \\
\text { intensive meadow }\end{array}$ & $\begin{array}{l}\text { Meadow } \\
\text { Wet meadow } \\
\text { Meadow with trees } \\
\text { Meadow with fruit trees } \\
\text { and grapevines } \\
\text { Meadow with fruit trees }\end{array}$ & $\begin{array}{l}\text { Meadow } \\
\text { Meadow with trees } \\
\text { Meadow with fruit trees }\end{array}$ & $\begin{array}{l}37.311 \text { Calcareus purple } \\
\text { moorgrass meadow } \\
\text { 37.2 Eutrophic humid } \\
\text { grasslands } \\
37.21 \text { Atlantic and sub- } \\
\text { Atlantic humid meadows } \\
\text { 37.211 Cabbage thistle } \\
\text { meadows } \\
81 \text { Improved grasslands }\end{array}$ & $\begin{array}{l}\text { 2.4.3 Land principally } \\
\text { occupied by agriculture, with } \\
\text { significant areas of natural } \\
\text { vegetation } \\
\text { 3.2.1 Natural grassland }\end{array}$ \\
\hline Vineyard & Vineyard & Vineyard & 83.21 Vineyards & 2.2.1 Vineyards \\
\hline Pasture & $\begin{array}{l}\text { Pasture } \\
\text { Pasture with trees } \\
\text { Pasture with fruit trees }\end{array}$ & $\begin{array}{l}\text { Pasture } \\
\text { Pasture with trees }\end{array}$ & 38.1 Mesophile pastures & 2.3 Pastures \\
\hline Wet pasture & Wet pasture & - & - & - \\
\hline Tall-herb communities & - & - & $\begin{array}{l}\text { 37.11 Western nemoral } \\
\text { tall-herb communities }\end{array}$ & $\begin{array}{l}3.2 \text { Shrub and/or herbaceous } \\
\text { vegetation associations }\end{array}$ \\
\hline Wetland & Marshes & - & $\begin{array}{l}\text { 53.1 Reed beds } \\
\text { 53.21 Large carex beds }\end{array}$ & 4.1.1 Inland marshes \\
\hline Peatland & - & Peatland & - & 4.1.2 Peatbogs \\
\hline Shrubland & $\begin{array}{l}\text { Pasture with shrubs } \\
\text { Pasture with shrubs and trees } \\
\text { Meadow with shrubs } \\
\text { Meadow with shrubs } \\
\text { and trees }\end{array}$ & - & $\begin{array}{l}\text { 38.13 Ruderalized } \\
\text { abandoned grasslands } \\
\text { 87.1 Fallow fields } \\
\text { 87.2 Ruderal communities } \\
\text { 87.2×31.8D/44.9 Ruderal } \\
\text { communities } \times \text { Western } \\
\text { Eurasian thickets / Alder, } \\
\text { willow, oak, aspen swamp } \\
\text { woods }\end{array}$ & $\begin{array}{l}\text { 3.2.4 Transitional } \\
\text { woodland/shrub }\end{array}$ \\
\hline Forest & $\begin{array}{l}\text { Young forest } \\
\text { Mature forest } \\
\text { Forest with fruit trees }\end{array}$ & $\begin{array}{l}\text { Young forest } \\
\text { Mature forest }\end{array}$ & $\begin{array}{l}\text { 84.3 Small woodlots } \\
\text { 83.311 Native conifer } \\
\text { plantations }\end{array}$ & 3.1 Forests \\
\hline Grove & - & Bushes & $\begin{array}{l}\text { 44.91 Alder swamp woods } \\
83.311 \text { Native conifer } \\
\text { plantations }\end{array}$ & $\begin{array}{l}\text { 3.2.4 Transitional } \\
\text { woodland/shrub }\end{array}$ \\
\hline Hedgerow & - & - & $\begin{array}{l}\text { 44.3 Middle European } \\
\text { stream ash-alder woods } \\
\text { 44.91 Alder swamp woods } \\
\text { 84.2 Hedges }\end{array}$ & 2.4.4 Agro-forestry areas \\
\hline River & River & River Stream & 24.1 River and streams & 5.1.1 Watercourses \\
\hline Channel & Channel & Channel & $\begin{array}{l}\text { 89.22 Ditches and small canals } \\
\text { 89.22/22.4 Ditches and small } \\
\text { canals/Euhydrophyte } \\
\text { communities }\end{array}$ & 5.1.2 Water bodies \\
\hline Pond & Pond & Pond & - & 5.1.2 Water bodies \\
\hline Built-up area & Built-up Cemetery Path & Built-up Path Passage & $\begin{array}{l}86 \text { Towns, villages, and } \\
\text { industrial sites } \\
\text { Paths and tracks Roads }\end{array}$ & $\begin{array}{l}1.1 \text { Urban fabric } \\
1.2 \text { Industrial, commercial, } \\
\text { and transport } \\
1.3 \text { Mine, dump, and } \\
\text { construction sites }\end{array}$ \\
\hline
\end{tabular}


additional criteria were added for »cultural/natural heritage and identity« (Table 3). We scored the generalized land use types from 0 to 5 according to their relevant capacity to supply each ecosystem service as determined by Burkhard et al. (2009) in Table 2. Then we corrected certain values of ecosystem services and adjusted them according to the actual state of landscape elements in the pilot areas determined by expert assessment (Čarni 2013). The results are shown in Table 3. To explore landscape changes and the consequent changes in their functions, three ecosystem services were studied in detail: pollination, crops, and cultural/natural heritage and identity.

Table 2: Matrix for assessing various land cover types' capacities to provide selected ecosystem goods and services (Burkhard et al. 2009).

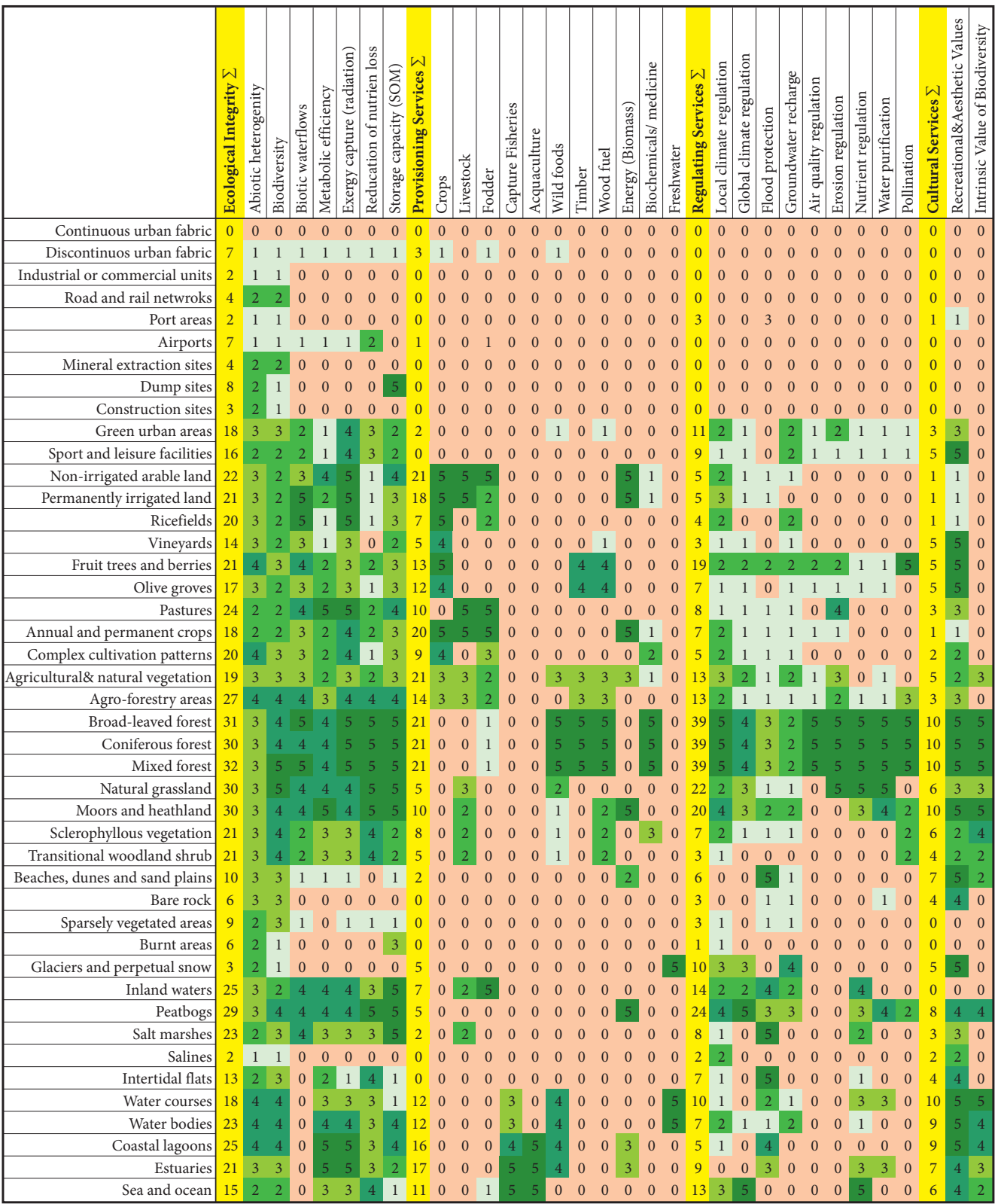


Furthermore, we prepared maps showing the capacity of land use types to supply ecosystem services (Figures 2 to 4). »Pollination, « representing the regulative group of ecosystem services, was chosen due to its importance for food production. Intensive agriculture using pesticides threatens bees and other pollinators (Klein et al. 2007). An additional threat to pollinators is the loss of their habitats. The ability to provide crops in the provisioning group of ecosystem services is the capacity of the landscape for food provision. From among the cultural ecosystem services, we selected the potential of providing »cultural/natural heritage and identity « because Slovenian cultural landscapes are recognized as valuable and are probably one of the main elements of national identity (Perko and Urbanc 2004, Golobič and Lestan 2016).

\section{Results}

\section{1 land use changes in the pilot areas}

In 1825 in Črna vas there were wet pastures, which later disappeared. In the same year drainage work started, resulting in the colonization of the Ljubljana Marsh in 1829. Over the following decades, Črna vas changed completely (Figure 1). In 1869, cultivated fields and meadows, separated by channels, characterized the landscape. In addition, groves and peatland were mapped. Peatlands were subjected to the greatest changes due to peat cutting (Melik 1927). The built-up area was introduced due to colonization. Some houses had fruit trees and gardens. In the third period studied, 2009-2013, the area became even more heterogeneous. The inhabitants shifted their activities towards animal husbandry, cultivated fields decreased, and meadows were intensified. The share of built-up area increased as well. Near houses, the proportion of vegetable gardens and ornamental gardens with fruit trees increased, replacing the extensive orchards. Areas of groves, among which we included bushes, have decreased. Due to abandonment, some areas have been overgrown with shrubland and non-native tall-herb communities. The native tall-herb communities present a special landscape element that provides a habitat for endangered bird species. However, due to changes in farming modes, tall-herb communities are decreasing. Pastures have appeared again. Hedgerows that were planted along the parcel borders by new inhabitants during the colonization after 1829 (as described in Melik 1927), and were not mapped in cadasters, have nowadays become a recognizable element of the landscape. Fragments of wetland have been found in abandoned channels. Rivers and channels are also present.

In Bojanci, cultivated fields showed a dramatic decrease from 1824 to 2011, although this change was more evident after 1877 (Figure 1). The areas occupied by gardens experienced fluctuations for the timespan studied. The area of vineyards is almost negligible and, as with gardens, this land use category also experienced slight fluctuations in the period studied. In 1824, extensive meadows and pastures dominated. Both meadows and pastures increased between 1824 and 1877, and decreased between 1877 and 2011. Pastureland almost disappeared in 2011, presumably as a result of afforestation. Shrubland occupied an extensive area in 1824; in 1877 this land use category was not mapped, whereas in the third period shrubland was mapped, although it occupied a much smaller proportion than the initial area. Even though forest area was already quite extensive in 1824 , the afforested land significantly expanded over time. Inland waters were negligible in 1824 and 1877, and these elements do not occur again after this period. The built-up area did not show major changes over more than 180 years; this could be understood as a sign of population stagnation. The major landscape changes in Bojanci took place after 1877. It was also reported by Ribeiro (2017) that the major peak of emigration was reached between 1912 and 1927, and so it was expected that the extent of land abandonment would increase as a result of emigration.

\subsection{Link between land use and ecosystem services}

Because landscape governance aims to be sustainable, it is important to know the functions and roles of ecosystems and individual landscape elements, and to manage landscapes accordingly. Therefore, based on the matrix from Table 2, values of ecosystem services were assigned for each landscape element. The result is presented in Table 3, in which landscape elements are sorted according to the total sum of all estimated values to supply ecosystem services. 
Daniela Ribeiro, Mateja Šmid Hribar, Assessment of land-use changes and their impacts on ecosystem services in two ...

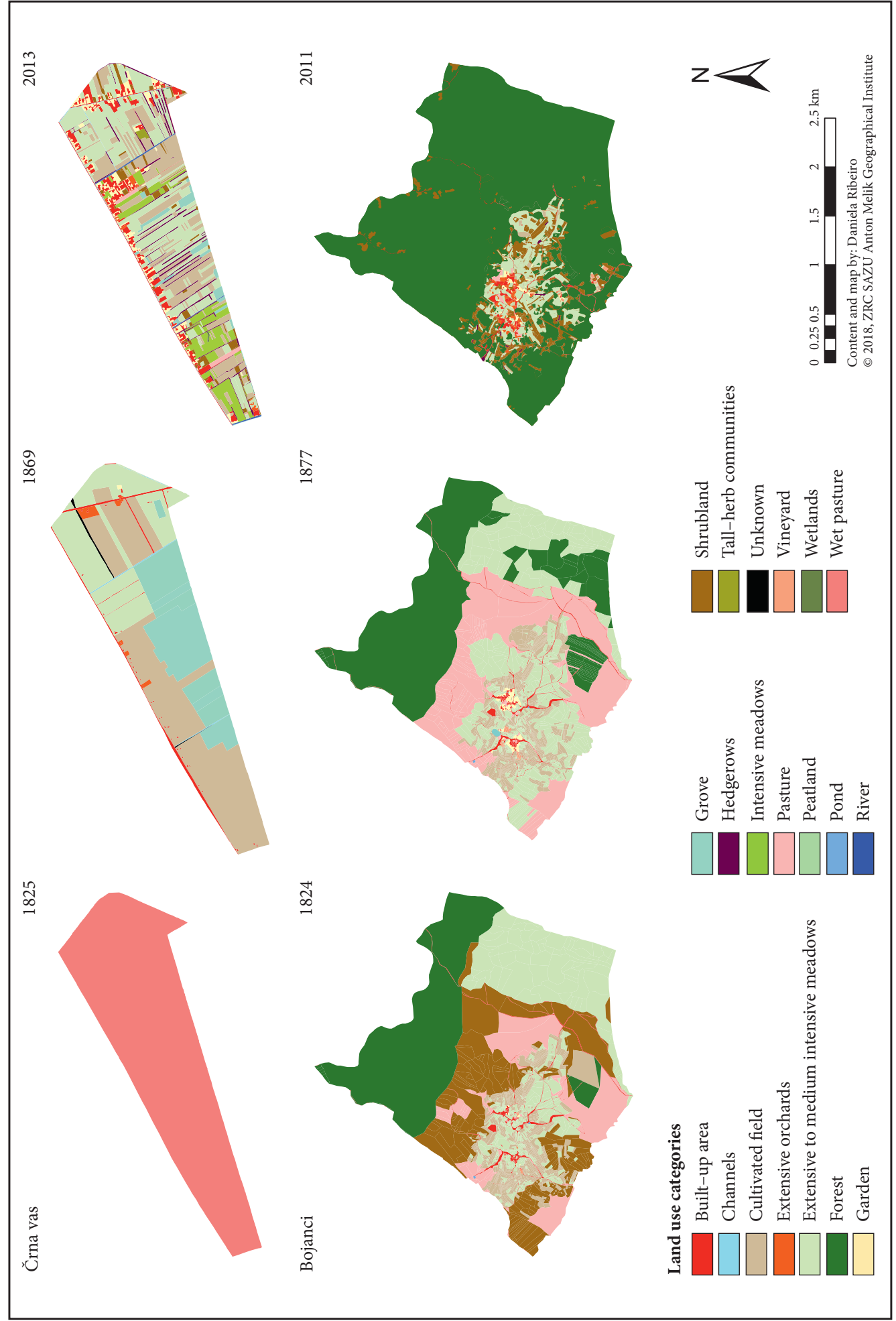




\begin{tabular}{|c|c|c|c|c|c|c|c|c|c|c|c|c|c|c|c|c|c|c|}
\hline & 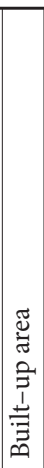 & & 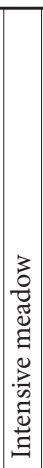 & ت্: & 壱 & $\mid$ & 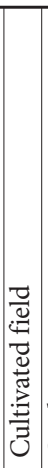 & 预 & 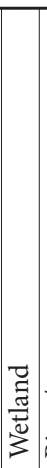 & 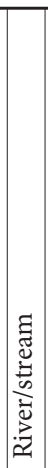 & 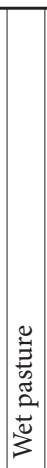 & . & 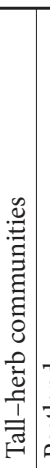 & 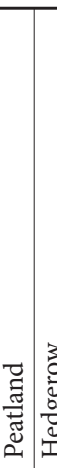 & 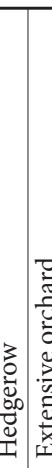 & 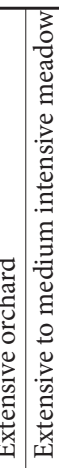 & 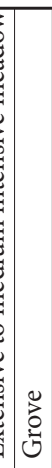 & 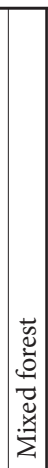 \\
\hline Total & 8 & 35 & 37 & 39 & 40 & 46 & 50 & 52 & 52 & 52 & 53 & 535 & 556 & 6168 & 6876 & 7681 & 96 & 105 \\
\hline Ecological integrity $\sum$ & 1 & 15 & 20 & 17 & 23 & 24 & 22 & 20 & 25 & 18 & 27 & 22 & 232 & 2719 & 1921 & 2127 & 730 & 32 \\
\hline Abiotic heterogenity & 1 & 3 & 2 & 3 & 4 & 2 & 3 & 3 & 3 & 4 & 3 & 3 & 2 & \begin{tabular}{l|l}
3 & 3 \\
\end{tabular} & \begin{tabular}{l|l}
3 & 4 \\
\end{tabular} & \begin{tabular}{l|l}
4 & 3 \\
\end{tabular} & 3 & 3 \\
\hline Biodiversity & 0 & 2 & 2 & 2 & 4 & 2 & 2 & 3 & 2 & 4 & 3 & 3 & 3 & 4 & 3 & 5 & 4 & 5 \\
\hline Biotic waterflows & 0 & 3 & 3 & 0 & 0 & 4 & 3 & 3 & 4 & 0 & 4 & 3 & 3 & 4 & 4 & 4 & 4 & 5 \\
\hline Metabolic efficiency & 0 & 1 & 4 & 3 & 4 & 5 & 4 & 2 & 4 & 3 & 5 & 3 & 3 & 4 & 2 & 3 & 4 & 4 \\
\hline Exergy capture (radiation) & 0 & 3 & 5 & 3 & 4 & 5 & 5 & 4 & 4 & 3 & 4 & 3 & 4 & 4 & 3 & 3 & 5 & 5 \\
\hline Reducation of nutrien loss & 0 & 1 & 1 & 3 & 3 & 2 & 1 & 2 & 3 & 3 & 3 & 4 & 4 & 4 & 2 & 4 & 5 & 5 \\
\hline Storage capacity (SOM) & 0 & 2 & 3 & 3 & 4 & 4 & 4 & 3 & 5 & 1 & 5 & 3 & 4 & 4 & 3 & 5 & 5 & 5 \\
\hline Regulating Services $\sum$ & $\mathbf{0}$ & 3 & 6 & 7 & 7 & 8 & 6 & 10 & 17 & 10 & 14 & 201 & 162 & 2122 & 2220 & \begin{tabular}{l|l}
20 & 27 \\
\end{tabular} & 734 & 39 \\
\hline Local climate regulation & 0 & I & 2 & 2 & 2 & 1 & 2 & 2 & 2 & 1 & 1 & 3 & 2 & \begin{tabular}{l|l}
4 & 3
\end{tabular} & \begin{tabular}{l|l}
3 & 3 \\
\end{tabular} & 3 & 4 & 5 \\
\hline Global climate regulation & 0 & 1 & 1 & 1 & 1 & 1 & 1 & 1 & 2 & 0 & 1 & 2 & 1 & 3 & 2 & 3 & 3 & 4 \\
\hline Flood protection & 0 & 0 & 1 & 1 & 1 & 1 & 1 & 1 & 4 & 2 & 3 & 2 & 2 & 3 & 1 & 2 & 2 & 3 \\
\hline Groundwater recharge & 0 & 1 & 1 & 2 & 2 & 1 & 1 & 1 & 2 & 1 & 2 & 2 & 2 & 2 & 2 & 2 & 3 & 2 \\
\hline Air quality regulation & 0 & 0 & 0 & 0 & 0 & 0 & 0 & 1 & 0 & 0 & 0 & 2 & 1 & 0 & 2 & 0 & 4 & 5 \\
\hline Erosion regulation & 0 & 0 & 1 & 0 & 0 & 3 & 0 & 1 & 0 & 0 & 2 & 3 & 2 & 0 & 3 & 4 & 5 & 5 \\
\hline Nutrient regulation & 0 & 0 & 0 & 1 & 1 & 0 & 0 & 1 & 3 & 3 & 3 & 1 & 2 & 3 & 1 & 4 & 4 & 5 \\
\hline Water purification & 0 & 0 & 0 & 0 & 0 & 0 & 0 & 0 & 4 & 3 & 1 & 2 & 2 & 4 & 1 & 5 & 4 & 5 \\
\hline Pollination & 0 & 0 & 0 & 0 & 0 & 1 & 1 & 2 & 0 & 0 & 1 & 3 & 2 & 2 & 5 & 4 & 5 & 5 \\
\hline Provisioning Services $\sum$ & $\mathbf{0}$ & 6 & 9 & 10 & 4 & 8 & 16 & 11 & 2 & 9 & 7 & 8 & 8 & \begin{tabular}{l|l}
6 & 17 \\
\end{tabular} & 1722 & \begin{tabular}{l|l}
22 & 13 \\
\end{tabular} & $\begin{array}{ll}318 \\
\end{array}$ & 22 \\
\hline Crops & 0 & 4 & 0 & 0 & 0 & 0 & 5 & 5 & 0 & 0 & 0 & 0 & 0 & 0 & 5 & 0 & 0 & 0 \\
\hline Livestock & 0 & 0 & 0 & 0 & 0 & 5 & 0 & 0 & 2 & 0 & 3 & 0 & 0 & 0 & 5 & 3 & 0 & 0 \\
\hline Fodder & 0 & 0 & 5 & 0 & 0 & 3 & 5 & 1 & 0 & 0 & 2 & 0 & 0 & 0 & 1 & 2 & 0 & 1 \\
\hline Capture Fisheries & 0 & 0 & 0 & 1 & 0 & 0 & 0 & 0 & 0 & 3 & 0 & 0 & 0 & 0 & 0 & 0 & 0 & 0 \\
\hline Acquaculture & 0 & 0 & 0 & 0 & 0 & 0 & 0 & 0 & 0 & 0 & 0 & 0 & 0 & 0 & 0 & 0 & 0 & 0 \\
\hline Wild food & 0 & 0 & 1 & 2 & 0 & 0 & 0 & 1 & 0 & 1 & 1 & 3 & 2 & 0 & 0 & 4 & 4 & 5 \\
\hline Timber & 0 & 0 & 0 & 0 & 0 & 0 & 0 & 0 & 0 & 0 & 0 & 0 & 0 & 0 & 4 & 0 & 5 & 5 \\
\hline Wood fuel & 0 & 1 & 0 & 0 & 0 & 0 & 0 & 1 & 0 & 0 & 1 & 2 & 0 & 1 & 4 & 0 & 5 & 5 \\
\hline Energy (Biomass) & 0 & 1 & 3 & 3 & 0 & 0 & 5 & 1 & 0 & 0 & 0 & 0 & 2 & 5 & 2 & 1 & 0 & 1 \\
\hline Biochemicals/medicine & 0 & 0 & 0 & 0 & 0 & 0 & 1 & 2 & 0 & 0 & 0 & 3 & 4 & 0 & 1 & 3 & 4 & 5 \\
\hline Freshwater & 0 & 0 & 0 & 4 & 4 & 0 & 0 & 0 & 0 & 5 & 0 & 0 & 0 & 0 & 0 & 0 & 0 & 0 \\
\hline Cultural Services $\Sigma$ & 7 & 11 & 2 & 5 & 6 & 6 & 6 & 11 & 8 & 15 & 5 & 3 & 8 & \begin{tabular}{l|l}
7 & 10 \\
\end{tabular} & \begin{tabular}{l|l}
0 & 13 \\
\end{tabular} & \begin{tabular}{l|l}
3 & 14
\end{tabular} & 414 & 12 \\
\hline Recreational values & 2 & 4 & 1 & 0 & 0 & 0 & 0 & 3 & 0 & 5 & 0 & 0 & 0 & 0 & 3 & 4 & 5 & 4 \\
\hline Aesthetic values & 2 & 3 & 1 & 2 & 2 & 3 & 3 & 4 & 4 & 5 & 3 & 3 & 5 & 4 & 5 & 5 & 5 & 4 \\
\hline $\mathrm{C} / \mathrm{N}$ heritage and identity & 3 & 4 & 0 & 3 & 4 & 3 & 3 & 4 & 4 & 5 & 2 & 0 & 33 & \begin{tabular}{l|l}
3 & 5 \\
\end{tabular} & \begin{tabular}{l|l}
5 & 5
\end{tabular} & \begin{tabular}{|l|l|}
5 & 5 \\
\end{tabular} & 4 & 4 \\
\hline
\end{tabular}




\subsection{Changes in the supply of selected ecosystem services as a result of landscape changes over 180 years}

The capacity to provide pollination in Črna vas was the greatest in 1869 (Figure 2), when this landscape was not as fragmented and intensively used as in 2013. In contrary, in Bojanci the capacity to provide pollination was the greatest in 2011 (Figure 2), when the forest area reached its maximum.

The best period for supporting crop provision in Črna vas was in 1869 (Figure 3) due to the high proportion of cultivated fields. Many of them were later transformed into various types of meadows and built-up areas. In Bojanci as well, the best period for supporting crop provision was in 1877 (Figure 3). After this period, the area experienced an increase in land abandonment as a result of emigration and consequently depopulation.

In Crna vas, the capacity for supplying cultural/natural heritage and identity started with the first inhabitants after 1829. Colonization introduced elements (channels, hedgerows, meadows, and cultivated fields) that later significantly influenced the identity of this landscape. However, nowadays some of them are being replaced by intensive meadows and shrublands, which are not contributing to current heritage and identity. The capacity for supplying cultural/natural heritage and identity in Bojanci was quite high in 1877 due to the increase in areas of pastures, meadows, and forests. This result might be due to the fact that shrubland was not mapped in 1877; the areas previously mapped as shrubland in 1824 were mapped as pastures or meadows in 1877 . According to the map, the greatest capacity to provide this cultural ecosystem service was achieved in 2011 (Figure 4), when the forested area was larger.

\section{Discussion}

We analyzed long-term land use changes in two pilot areas from 1824 to 2013 (Figure 1). Due to a lack of data from 1900 to 2000, the intervals between the datasets are unequal, but this did not affect the main goal of the study.

The study of land use changes in Črna vas has shown that since 1825 the main driving forces of the area were agriculture, settlement, and water management, which introduced a number of new landscape elements yielding various ecosystem services. In recent decades, nature protection became an important driving force, resulting in declaring the Ljubljana Marsh a protected landscape area in 2008. This protection has limited intensified agriculture and, in addition to regular agricultural subsidies, has also introduced specific ones. However, the system of subsidies has a voluntary basis, enabling farmers to make their own decisions. All of this has resulted in the simultaneous presence of two opposite trends: intensification and abandonment accompanied by the disappearance of managing the landscape in less intensive manners that are closer to nature. Elements such as wet pastures, peatland, and partly also groves and extensive orchards have almost disappeared in Črna vas as a result of ongoing agricultural intensification. Without sustainable governance, this trend will continue leading to fragmentation and the disappearance of low-intensity landscape usage elements, which are important for providing more diverse ecosystem services.

Land management is lacking in Bojanci, and landscape elements are being transformed into other elements. Land abandonment may contribute to the natural restoration of the landscape on the one hand, and it may threaten the functional diversity of cultural landscapes on the other hand.

Landscape elements such as cultivated fields or meadows have practically disappeared in Bojanci in recent times. This phenomenon can be explained primarily as the result of the retreat of agriculture from unfavorable areas and rural depopulation.

The method applied made it possible to assess ecosystem services based on land use (Table 3). The originality of this paper lies in its application of the method to land use at the parcel level from three time periods, making it possible to show the influence of land use changes on the capacity to provide ecosystem services (Figures 2-4). 


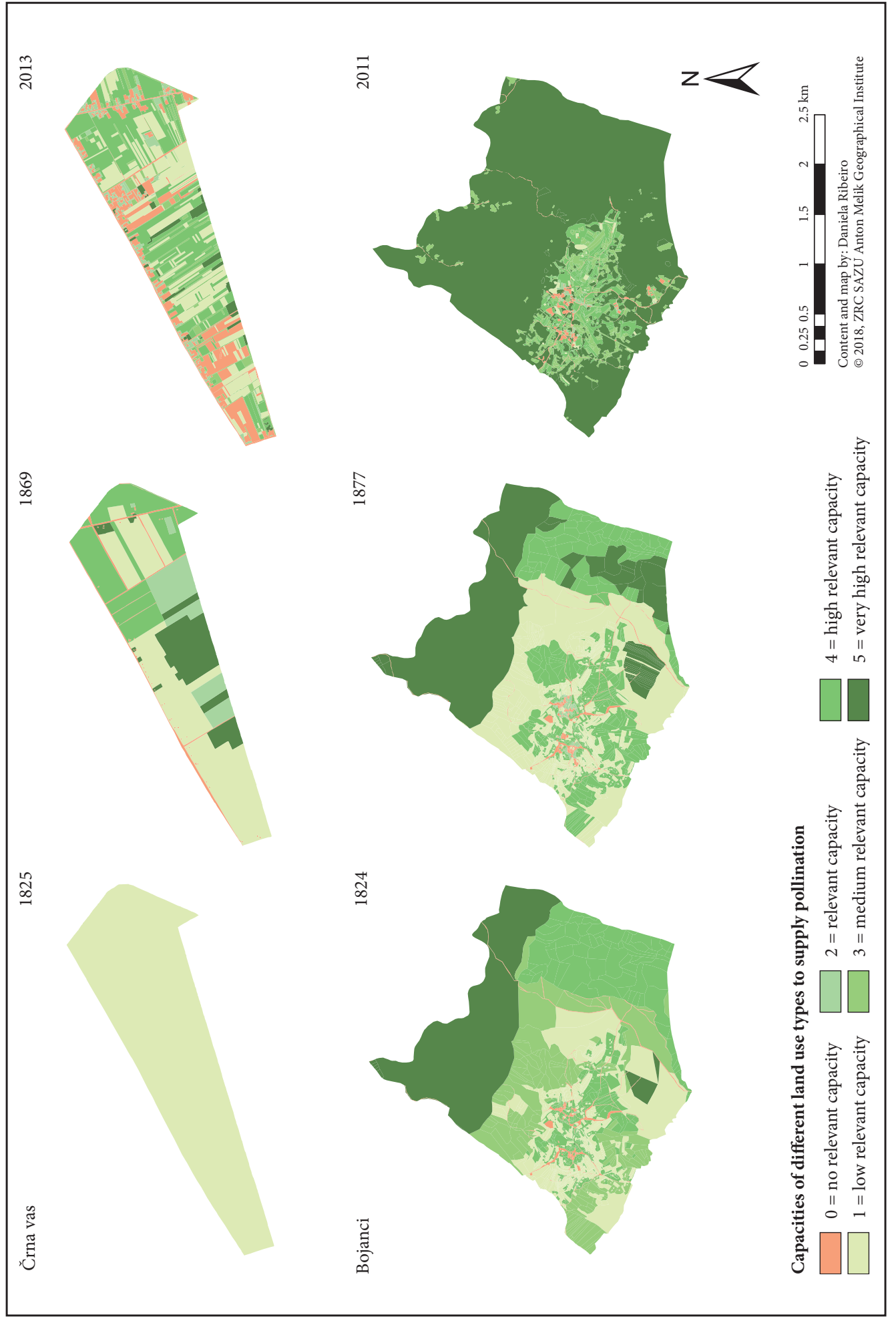


Daniela Ribeiro, Mateja Šmid Hribar, Assessment of land-use changes and their impacts on ecosystem services in two ...

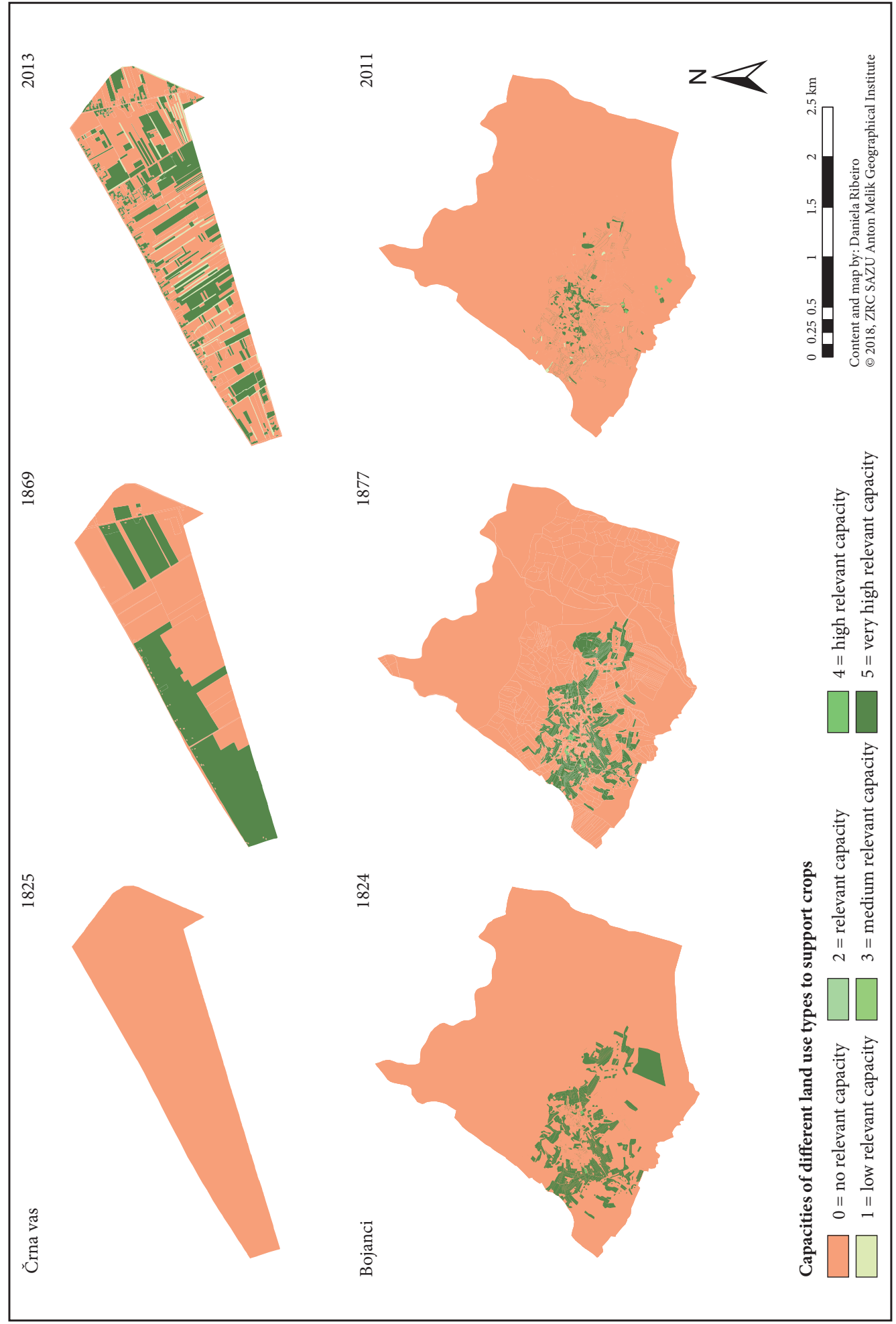




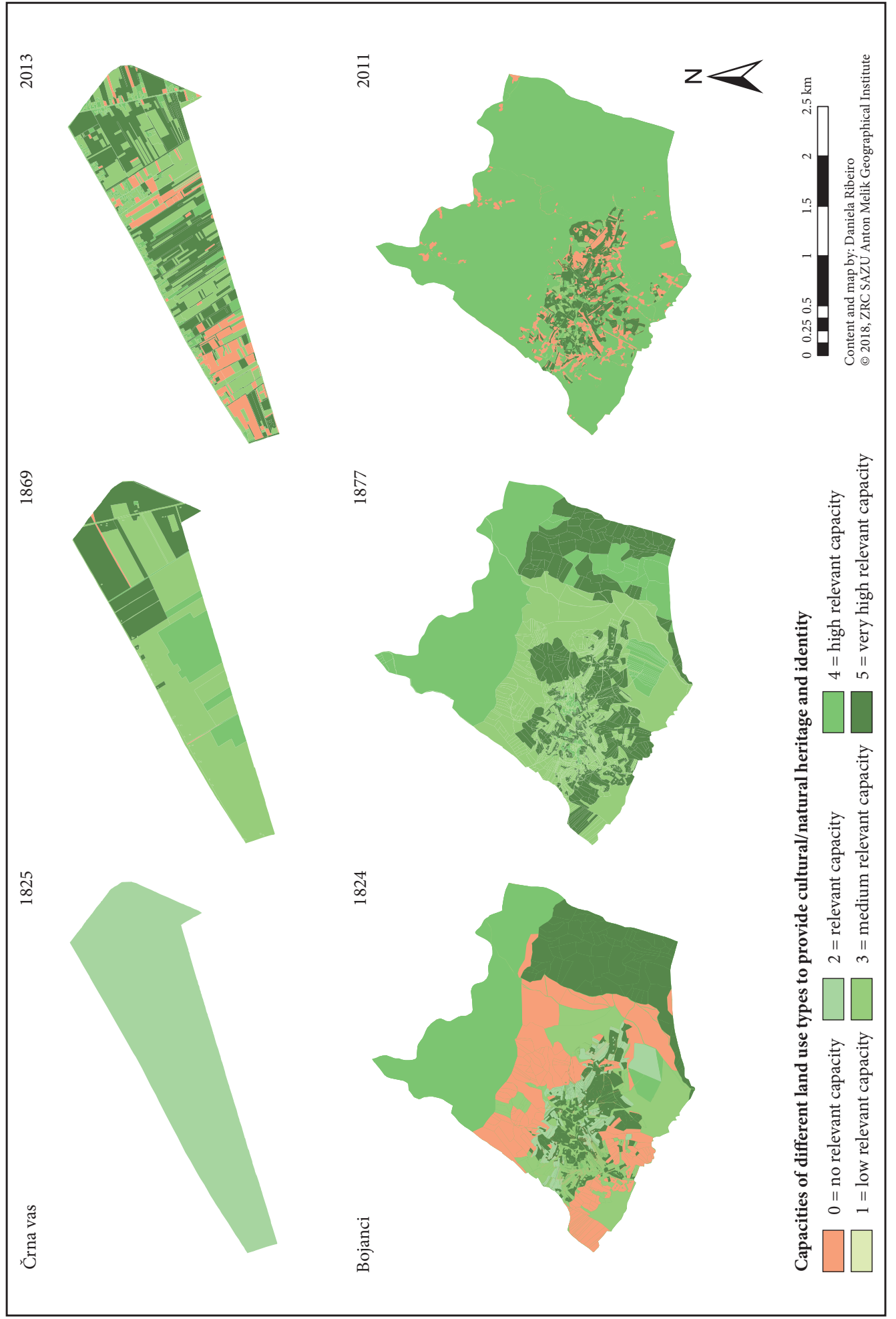


In Črna vas, the provision of ecosystem services studied was higher in 1869. In this pilot area neither a lack of agriculture (mapped in 1825) nor intensive agricultural use (mapped in 2013) positively contributes to a balanced provision of regulating and provisioning ecosystem services. Cultural ecosystem services increased with colonization; however, they are now threatened by synchronous intensification and abandonment.

Land abandonment in Bojanci is leading to an increase in regulating ecosystem services and to a decrease in provisioning ecosystem services. Cultural ecosystem services increased in Bojanci recently following the expansion of forests. The high relevant capacity for provisioning heritage and identity attributed to Bojanci in 2011, shown in Figure 4, is arguable because this abandoned landscape has resulted in an expansion of forested land. This points to a critical aspect of the methodology used. We assigned forest a high value for cultural services because forests are much appreciated and highly important for Slovenians. However, the aesthetic value of mosaic landscapes with a diversity of land use patches is here not taken in account. We are aware that not all forested areas support the same level of these ecosystem services. Therefore, on the one hand, for some cultural ecosystem services it would be more accurate to assign values for specific points (e.g., monuments and viewpoints) and not for the landscape element as a whole. On the other hand, a landscape itself can sometimes be recognized as heritage and national identity (Lowenthal 2007).

We suggest that cultural ecosystem services should be further studied and elaborated using systematic field walk based analysis as proposed by Bieling and Plieninger (2013) and interviews as mentioned by Bieling et al. (2014).

Based on the landscape changes studied, we argue that preservation of traditional and low-intensity agriculture should be promoted to protect against the overgrowth of agricultural land and that intensive use of agricultural land should be restricted due to the importance of preserving cultural landscapes and providing diverse ecosystem services (e.g., food provisioning and preservation of cultural heritage/identity, which consequently attracts tourism). In addition, the findings of this study should influence incentive-based policies (e.g., the future Common Agricultural Policy), which should be better adapted to local contexts and characteristics.

\section{Conclusions}

With this study we linked land use with ecosystem services. We are aware that the ecosystem service values used in this study are only an approximation, and detailed studies should be carried out for a more accurate assessment.

A comparison of selected ecosystem services provided over 180 years for the pilot areas revealed that provisioning and cultural services were significantly reduced in Bojanci due to land abandonment and depopulation, whereas these ecosystem services increased due to colonization and the proliferation of arable land in Črna vas. On the other hand, for exactly the same reasons, regulating ecosystem services increased in Bojanci in recent decades, but they decreased in Črna vas during the same time period.

It also turned out that land use data are not always relevant for mapping the supply of cultural ecosystem services. Nevertheless, from the estimated values shown in Table 3 it is already evident that less intensively used landscape elements contribute to more numerous and diverse ecosystem services than landscape elements with more intense use or abandoned ones. This finding should be taken into account in landscape management, which should consider natural characteristics and try to maintain those landscape elements that require little input while still offering various ecosystem services.

The approach presented can be used as a support tool for decision-making in managing and governing landscapes. Furthermore, the study opens an arena for theoretical discussion between various disciplines (e.g., geography, ecology, forestry, and sociology) that should contribute to understanding the landscape as a complex integrated whole.

ACKNOWLEDGEMENT: The authors acknowledge the financial support from the Slovenian Research Agency research core funding Geography of Slovenia (P6-0101) and Infrastructure programme (I0-0031). 


\section{References}

Bender, O., Boehmer, H. J., Jens, D., Schumacher, K. P. 2005: Using GIS to analyse long-term cultural landscape change in Southern Germany. Landscape and Urban Planning 70, 1-2. DOI: https://doi.org/10.1016/ j.landurbplan.2003.10.008

Bieling, C., Plieninger, T. 2013: Recording manifestations of cultural ecosystem services in the landscape. Landscape Research 38-5. DOI: https://doi.org/10.1080/01426397.2012.691469

Bieling, C., Plieninge T., Pirker, H., Vogl, C. R. 2014: Linkages between landscapes and human well-being: An empirical exploration with short interviews. Ecological Economics 105. DOI: https://doi.org/10.1016/ j.ecolecon.2014.05.013

Braat, L., Klok, C., Walpole, M., Kettunen, M., Peralta-Bezerra, N., ten Brink, P. 2008: Changes in ecosystem services. The cost of policy inaction- the case of not meeting the 2010 biodiversity target. Wageningen.

Bürgi, M., Silbernagel, J., Wu, J., Kienast, F. 2015: Linking ecosystem services with landscape history. Landscape Ecology 30-1. DOI: https://doi.org/10.1007/s10980-014-0102-3

Burkhard, B., Kroll, F., Müller, F., Windhorst, W. 2009: Landscapes' capacities to provide ecosystem services a concept for land-cover based assessments. Landscape Online 15. DOI: https://doi.org/10.3097/ LO.200915

Burkhard, B., Kroll, F., Nedkov, S., Müller, F. 2012: Mapping ecosystem service supply, demand and budgets. Ecological Indicators 21. DOI: https://doi.org/10.1016/j.ecolind.2011.06.019

Ceschia, E., Béziat, P., Dejoux, J. F., Aubinet, M., Bernhofer, C., Bodson, B., Buchmann, N., Carrara, A., Cellier, P., Di Tommasi, P., Elbers, J. A., Eugster, W., Grünwald, T., Jacobs, C. M. J., Jans, W. W. P., Jones, M., Kutsch, W., Lanigan, G., Magliulo, E., Marloie, O., Moors, E. J., Moureaux, C., Olioso, A., Osborne, B., Sanz, M. J., Saunders, M., Smith, P., Soegaard, H., Wattenbach, M. 2010: Management effects on net ecosystem carbon and GHG budgets at European crop sites. Agriculture, Ecosystems \& Environment 139-3. DOI: https://doi.org/10.1016/j.agee.2010.09.020

Ciglič, R., Hrvatin, M., Komac, B., Perko, D. 2012: Karst as a criterion for defining areas less suitable for agriculture. Acta geographica Slovenica 52-1. DOI: https://doi.org/10.3986/AGS52103

Čarni, A., 2013: Evaluation of ecosystem services. Personal communication. Ljubljana.

Čarni, A., Čelik, T., Dakskobler, I., Košir, P., Juvan, N., Marinšek, A., Sajko, I., Šilc, U., Vreš, B. 2011: Kartiranje negozdnih habitatnih tipov Slovenije: območje Reka, Marindol, Volčeke, Kras - Lokev, Mirna. Ljubljana.

de Groot, R. S., Alkemade, R., Braat, L., Hein, L., Willemen, L. 2010: Challenges in integrating the concept of ecosystem services and values in landscape planning, management and decision making. Ecological Complexity 7-3. DOI: https://doi.org/10.1016/j.ecocom.2009.10.006

Dražumerič, M. 1987: Izseljevanje iz Bele krajine od začetkov do druge svetovne vojne. Traditiones 16.

Erjavec, D., Govedič, M., Grobelnik, V., Jakopič, M., Trčak, B. 2009: Monitoring zavarovanih negozdnih habitatnih tipov v Mestni občini Ljubljana. Ljubljana. Internet: https://www.ljubljanskobarje.si/uploads/ datoteke/Porocilo_MOL_ht.pdf (31.10.2013).

European Environmental Agency, 1995: CORINE land cover. Internet: https://www.eea.europa.eu/ publications/COR0-landcover (8.1.2018).

European Landscape Convention, 2000. Internet: https://www.pcl-eu.de/project/convention/intro.php? PHPSESSID $=4 \mathrm{~d} 2 \mathrm{ef} 5 \mathrm{~d} 6833223 \mathrm{~d} 11 \mathrm{cf} 81320 \mathrm{~b} 70026 \mathrm{ac}(8.1 .2018)$.

Fisher, B., Turner, R. K., Morling, P. 2009: Defining and classifying ecosystem services for decision making. Ecological Economics 68-3. DOI: https://doi.org/10.1016/j.ecolecon.2008.09.014

Franciscejski kataster za Kranjsko, SI AS 176, k. o. Bojanci, N19, list A01, list A02, list A03, list A04. Arhiv Republike Slovenije, Ljubljana. 1824.

Franciscejski kataster za Kranjsko, SI AS 176, k. o. Bojanci, N19, Seznam zemljiških parcel. Arhiv Republike Slovenije, Ljubljana. 1824.

Franciscejski kataster za Kranjsko, SI AS 176, k. o. Trnovsko predmestje, L303, list A06, list A08, list A09. Arhiv Republike Slovenije, Ljubljana. 1825.

Franciscejski kataster za Kranjsko, SI AS 176, k. o. Trnovsko predmestje, L303. Seznam zemljiških parcel. Arhiv Republike Slovenije, Ljubljana. 1825.

Frélichová, J., Fanta, J. 2015: Ecosystem service availability in view of long-term land use changes: a regional case study in the Czech Republic. Ecosystem Health and Sustainability 1-10. DOI: https://doi.org/ 10.1890/EHS15-0024.1 
Fry, G., Gustavsson, R. 1996: Testing landscape design principles: the Landscape Laboratory. Ecological and landscape consequences of land use change. European Centre for Nature Conservation Publication Series on Man and Nature 2. Tilburg.

Gabrovec, M., Kladnik, D. 1997: Nekaj novih vidikov rabe tal v Sloveniji. Geografski zbornik 37.

Gabrovec, M., Kumer, P. 2019: land use changes in Slovenia from the Franciscean Cadaster until today. Acta geographica Slovenica 59-1. DOI: https://doi.org/10.3986/AGS.4892

Golobič, M., Lestan, K. A. 2016: Potential impacts of EU policies on cultural landscape diversity: example of Slovenian coastal landscapes. Annales 26-2. DOI: https://doi.org/10.19233/ASHS.2016.16

Habitatni tipi na Ljubljanskem barju, 2009. Digital map, Center za kartografijo favne in flore. Miklavž na Dravskem polju.

Haines-Young, R., Potschin, M., Kienast, F. 2012: Indicators of ecosystem service potential at European scales: Mapping marginal changes and trade-offs. Ecological Indicators 21. DOI: https://doi.org/10.1016/ j.ecolind.2011.09.004

Hladnik, D. 2005: Spatial structure of disturbed landscapes in Slovenia. Ecological Engineering 24, 1-2. DOI: https://doi.org/10.1016/j.ecoleng.2004.12.004

Klein, A. M, Vaissiere, B. E., Cane, J. H., Steffan-Dewenter, I., Cunningham, S. A., Kremen, C., Tscharntke, T. 2007: Importance of pollinators in changing landscapes for world crops. Proceedings of Royal Society 274. DOI: https://doi.org/10.1098/rspb.2006.3721

Kumar, P. (ed.) 2010: The economics of ecosystems and biodiversity: Ecological and economic foundations. London.

Lisec, A., Pišek, J., Drobne, S. 2013: Suitability analysis of land use records of agricultural and forest land for detecting land use change on the case of the Pomurska Statistical Region. Acta geographica Slovenica 53-1. DOI: https://doi.org/10.3986/AGS53104

Lowenthal, D. 2007: Living with and looking at landscape. Landscape Research 32-5. DOI: https://doi.org/ $10.1080 / 01426390701552761$

Makovníková, J., Kanianska, R., Kizekova, M. 2017: The ecosystem services supplied by soil in relation to land use. Hungarian Geographical Bulletin 66-1. DOI: https://doi.org/10.15201/hungeobull.66.1.4

Mander, Ü., Uuemaa, E. 2010: Landscape assessment for sustainable planning. Ecological indicators 10-1. DOI: https://doi.org/10.1016/j.ecolind.2009.08.003

Mauerhofer, V., Ichinose, T., Blackwell, B. D., Willig, M. R., Flint, C. G., Krause, M. S., Penker, M. 2018: Underuse of social-ecological systems: A research agenda for addressing challenges to biocultural diversity. Land Use Policy 72. DOI: https://doi.org/10.1016/j.landusepol.2017.12.003

Melik, A. 1927: Kolonizacija Ljubljanskega barja. Ph.D. thesis, Univerza Kraljevine Srbov Hrvatov In Slovencev. Ljubljana.

Millenium Ecosystem Assesment, 2005: Ecosystems and human well-being: Synthesis. Washington. Internet: https://www.millenniumassessment.org/documents/document.356.aspx.pdf (13. 11.2017).

Otieno, M., Woodcock, B. A., Wilby, A., Vogiatzakis, I. N., Mauchline, A. L., Gikungu, M. W., Potts, S. G. 2011: Local management and landscape drivers of pollination and biological control services in a Kenyan agro-ecosystem. Biological Conservation 144-10. DOI: https://doi.org/10.1016/j.biocon.2011.06.013

Paušič, A., Čarni, A. 2012: Landscape transformation in the low karst plain of Bela krajina (SE Slovenia) over the last 220 years. Acta geographica Slovenica 52-1. DOI: https://doi.org/10.3986/AGS52102

Perko, D., Urbanc, M. 2004: Landscape research in Slovenia. Belgeo 2-3. DOI: https://doi.org/10.4000/ belgeo.13618

Petek, F. 2002: Methodology of evaluation of changes in land use in Slovenia between 1896 and 1999. Acta geographica Slovenica 42-1.

Petek, F., Urbanc, M. 2004: The Franziscean Land Cadastre as a key to understanding the 19th-century cultural landscape in Slovenia. Acta geographica Slovenica 44-1. DOI: https://doi.org/10.3986/AGS44104

Plut, D. 2008: Osnovne geografske značilnosti Bele krajine. Bela krajina in Krajinski park Lahinja. Ljubljana.

Reambulančni kataster za Kranjsko, k. o. Bojanci. Geodetska uprava Republike Slovenije, Geodetska pisarna Črnomelj. 1877.

Reambulančni kataster za Kranjsko, SI AS 181, k. o. Bojanci, N19, Seznam zemljiških parcel. Arhiv Republike Slovenije, Ljubljana. 1877. 
Reambulančni kataster za Kranjsko, SI AS 181, k. o. Trnovsko predmestje, L303, list A06, list A08, list A09. Arhiv Republike Slovenije, Ljubljana. 1869.

Reambulančni kataster za Kranjsko, SI AS 181, k. o. Trnovsko predmestje, L303, Seznam zemljiških parcel. Arhiv Republike Slovenije, Ljubljana. 1869.

Ribeiro, D., Ellis Burnet, J., Torkar, G. 2013: Four windows on Borderlands: Dimensions of place defined by land cover change data from historical maps. Acta geographica Slovenica 53-2. DOI: https://doi.org/ 10.3986/AGS53204

Ribeiro, D. 2017: Impact of landscape features on land use and regional development in karst areas: a case study of Bela krajina. Ph.D. thesis, University of Ljubljana. Ljubljana.

Ribnikar, P. 1982: Zemljiški kataster kot vir za zgodovino. Zgodovinski časopis 36-4.

Smrekar, A., Šmid Hribar, M., Tiran, J., Erhartič, B. 2016: A methodological basis for landscape interpretation: the case of the Ljubljana Marsh. Acta geographica Slovenica 56-2. DOI: https://doi.org/10.3986/AGS.875

Šmid Hribar, M. 2016: Varovanje in trajnostni razvoj kulturne pokrajine na primeru Ljubljanskega barja. Georitem 27. Ljubljana. 